OPEN ACCESS

Edited by:

Gordon T. Taylor,

Stony Brook University, United States

Reviewed by:

Mustafa Yucel,

Middle East Technical University,

Turkey

William D. Leavitt,

Dartmouth College, United States

${ }^{*}$ Correspondence:

Gilad Antler

giladantler@gmail.com

Specialty section:

This article was submitted to

Microbiological Chemistry

and Geomicrobiology,

a section of the journal

Frontiers in Microbiology

Received: 23 May 2017

Accepted: 08 March 2018

Published: 06 April 2018

Citation:

Antler G and Pellerin A (2018)

A Critical Look at the Combined Use

of Sulfur and Oxygen Isotopes

to Study Microbial Metabolisms

in Methane-Rich Environments.

Front. Microbiol. 9:519.

doi: 10.3389/fmicb.2018.00519

\section{A Critical Look at the Combined Use of Sulfur and Oxygen Isotopes to Study Microbial Metabolisms in Methane-Rich Environments}

\author{
Gilad Antler ${ }^{1,2,3 *}$ and André Pellerin ${ }^{4}$ \\ ${ }^{1}$ Department of Earth Sciences, University of Cambridge, Cambridge, United Kingdom, ${ }^{2}$ Department of Geological and \\ Environmental Sciences, Ben-Gurion University of the Negev, Beersheba, Israel, ${ }^{3}$ The Interuniversity Institute for Marine \\ Sciences, Eilat, Israel, ${ }^{4}$ Center for Geomicrobiology, Department of Bioscience, Aarhus University, Aarhus, Denmark
}

Separating the contributions of anaerobic oxidation of methane and organoclastic sulfate reduction in the overall sedimentary sulfur cycle of marine sediments has benefited from advances in isotope biogeochemistry. Particularly, the coupling of sulfur and oxygen isotopes measured in the residual sulfate pool $\left(\delta^{18} \mathrm{O}_{\mathrm{SO} 4}\right.$ vs. $\left.\delta^{34} \mathrm{~S}_{\mathrm{SO} 4}\right)$. Yet, some important questions remain. Recent works have observed patterns that are inconsistent with previous interpretations. We differentiate the contributions of oxygen and sulfur isotopes to separating the anaerobic oxidation of methane and organoclastic sulfate reduction into three phases; first evidence from conventional high methane vs. low methane sites suggests a clear relationship between oxygen and sulfur isotopes in porewater and the metabolic process taking place. Second, evidence from pure cultures and organic matter rich sites with low levels of methane suggest the signatures of both processes overlap and cannot be differentiated. Third, we take a critical look at the use of oxygen and sulfur isotopes to differentiate metabolic processes (anaerobic oxidation of methane vs. organoclastic sulfate reduction). We identify that it is essential to develop a better understanding of the oxygen kinetic isotope effect, the degree of isotope exchange with sulfur intermediates as well as establishing their relationships with the cell-specific metabolic rates if we are to develop this proxy into a reliable tool to study the sulfur cycle in marine sediments and the geological record.

Keywords: sulfur isotopes, oxygen isotopes, anaerobic oxidation of methane (AOM), sulfate reduction rates, marine sediments

\section{INTRODUCTION}

Methane is an important greenhouse gas which moderates the climate of the planet and marine sediments are Earth's largest methane reservoir and production site (Whiticar et al., 1986; Kvenvolden, 1988). In the distant past, fluxes of methane from marine pelagic environments may have triggered abrupt warming periods (Dickens et al., 1995) and understanding the controls on its production and release is of interest for predictions of climate change and reconstruction of Earth's past. A continuous flux of methane from biotic and thermogenic origins diffuses or escapes from production zones toward the surface. The distinct zone where upward diffusion of methane meets with the downward diffusion of sulfate from seawater is called the sulfate methane transition zone. This zone is where the anaerobic oxidation of methane by sulfate (hereafter 'AOM-SR') is 
catalyzed by consortia of bacteria and archaea who derive energy for growth by reacting the two together (Boetius et al., 2000). This leads to the quasi-quantitative consumption of both substrates, the establishment of steady state concentration profiles and the oxidation of a large fraction of the flux of methane, which would otherwise diffuses upward into the ocean (Wuebbles and Hayhoe, 2002). Sulfate is also consumed by sulfate reducing microorganisms which couple the oxidation of organic matter deposited on the seafloor with the reduction of sulfate (hereafter organoclastic sulfate reduction - OSR).

Separating the contributions of OSR and AOM-SR to the overall sedimentary sulfur cycle has been challenging but has benefited from recent advances in isotope biogeochemistry. Stable carbon isotopes have been vastly used to address these processes. Recently, the coupling of sulfur and oxygen isotopes measured in the residual sulfate pool $\left(\delta^{18} \mathrm{O}_{\mathrm{SO}} 4\right.$ vs. $\left.\delta^{34} \mathrm{~S}_{\mathrm{SO} 4}\right)$ has also been demonstrated to be instrumental in our understanding of the interactions between the carbon and sulfur cycles. Metabolic processes discriminate between light and heavy isotopologues and the progressive enrichments in heavy isotoplogues observed in the residual sulfate pool can trace this activity. Oxygen and sulfur isotopes are sensitive to the reductive pathway and geochemical conditions under which multiple biological and abiotic reactions occur (Brunner et al., 2005; Turchyn et al., 2006; Wortmann et al., 2007). Yet, similar to other proxies, the combined S-O isotopes in porewater sulfate is propagating on Elderfield's proxy confidence curve [from the 'Optimism phase,' through the 'Pessimism phase,' to the 'Realism phase'-(Elderfield, 2002)]. With recent works observing $\delta^{18} \mathrm{O}_{\mathrm{SO} 4}$ vs. $\delta^{34} \mathrm{~S}_{\mathrm{SO} 4}$ patterns that are inconsistent with previously held interpretations, we ask: what are the limits of application of the combined sulfur-oxygen isotope tool to distinguish between AOM-SR and OSR?

\section{THE OPTIMISM PHASE}

In a given pore water profile, the slope of the tangent on the $\delta^{18} \mathrm{O}_{\mathrm{SO} 4}$ vs. $\delta^{34} \mathrm{~S}_{\mathrm{SO} 4}$ (slope of the apparent linear phase-SALP) is related to the overall sulfate reduction rate (SRR) where lower rates lead to steeper SALP (see Figure 1) (Böttcher et al., 1998, 1999; Aharon and Fu, 2000; Brunner et al., 2005; Antler et al., 2013). The negative relationship between SALP and SRR is understood as increased reversibility of the sulfate reducing enzymatic pathway (Fritz et al., 1989; Brunner and Bernasconi, 2005). The SALP is also affected by sulfur cycling extracellularly where waste products of sulfate reduction can be reoxidized. For example, disproportionation will lead to higher SALP values (Böttcher and Thamdrup, 2001; Böttcher et al., 2001, 2005; Blonder et al., 2017). These relationships are utilized to study the sulfur cycle in marine sediments.

In pelagic regions of the oceans, where the sedimentation rate and supply of organic carbon is relatively low, most of the organic matter remineralization occurs through OSR and only a small fraction of mineralization is via methanogenesis. Under these conditions, sulfate reduction proceeds under organic matter limitation (Glombitza et al., 2015). This results in pore

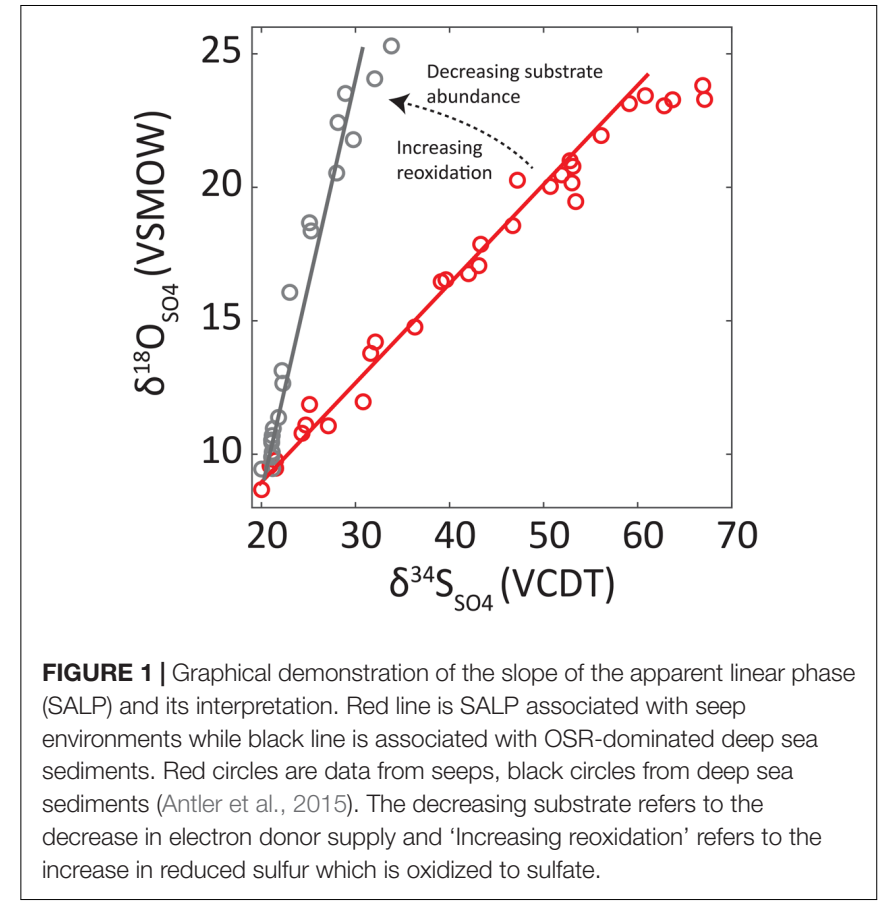

water profiles characterized by high SALP numbers (Figure 2, gray bars). On the other hand, sites with a high organic carbon flux to the seafloor results in excess methane diffusing upward and leads to low SALP numbers. In fact, methanerich environments interestingly fall in a very narrow range of SALPs (see highlighted 'seeps' range, Figure 2). AOMSR-dominated sites record maximum SALP values of $\sim 0.4$ (Figure 2) and reflect the fact that these environments are not electron donor (methane) limited and thus have low reversibility (Antler et al., 2015). Indeed, low SALP appears to be universal for methane rich environments, regardless of the ambient temperature, water depth (or pressure), salinity and sedimentation rate (Antler et al., 2015; Feng et al., 2016). Therefore, it appears SALP may distinguish between OSR and AOM-SR, even when sulfate concentration profiles are similar in their sulfate penetration depth (Antler et al., 2014). Overall, this tool seems to be robust under different environmental conditions and a great potential for both modern and geological applications.

\section{THE PESSIMISM PHASE}

However, observations of low SALP in organic-rich, OSRdominated sediments of marine mangroves (slope of $0.36 \pm 0.06$; Crémière et al., 2017) questions the robustness of SALP to identify AOM-SR dominated environments. This suggests that low SALPs are not unique to AOM-SR in the environment. (Figure 2; green bars). To address this issue, we compiled SALP data from sites that are likely to be AOM-SR dominated as well as sites that are OSR dominated (Figure 2, red bars and green bars, respectively). It appears there is no significant difference in SALP between AOM-SR and some OSR dominated environments. This 


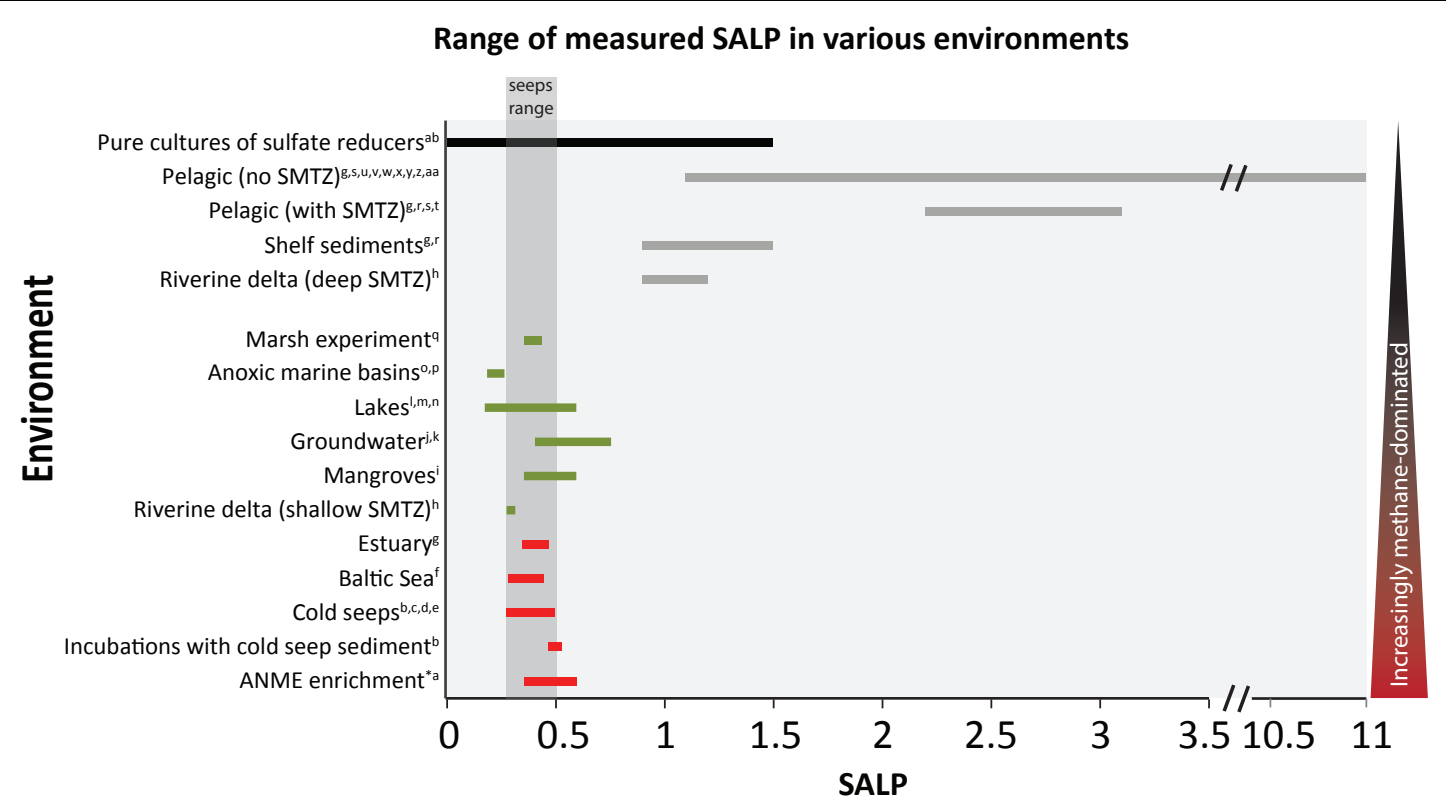

FIGURE 2 | Slope of the apparent linear phase (SALP) measured in various environments. Note the broken axis between 3.5 and 10.5. Black bar indicates pure cultures of dissimilatory sulfate reducers, gray bars specify environments where methane is thought to play a minor role according to the reference. Green bars indicate environments where the presence and contribution of methane to the overall removal of sulfate is questionable. Red bars indicate environments that are thought to be methane dominated. Gray dashed line indicates the SALP measured in methane seeps. Triangle grading from black to red is meant to demonstrate the overall increase in methane in that specific environment. Data (Deusner et al., 2014) $)^{\mathrm{a}}$, (Sivan et al., 2014) $)^{\mathrm{b}}$, (Aharon and Fu, 2000) $)^{\mathrm{c}}$, (Aharon and Fu, 2003) ${ }^{\mathrm{d}}$,

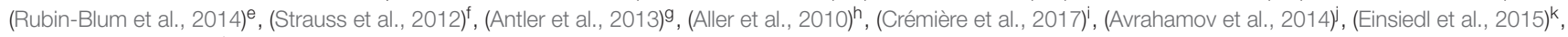

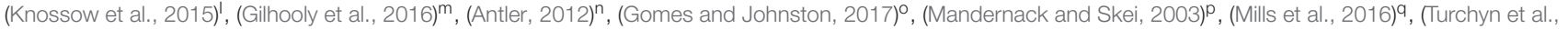


2006)y , (Turchyn et al., 2016)z, (Wortmann et al., 2007) ${ }^{\mathrm{aa}}$, (Antler et al., 2017) ${ }^{\mathrm{ab}} \cdot{ }^{*}$ Indicates SALP values are calculated.

means that the SALP does not provide sufficient information to distinguish between these two processes.

Pure cultures of sulfate reducing microorganisms (Figure 2, black bar) are analogous in metabolic pathway to OSR in marine sediments and are useful to discuss the limits of SALP associated with this metabolism. They have been demonstrated to produce the entire range of SALPs observed in nature with the exception of pelagic sites (Figure 2; gray bars). In pure culture, a near zero SALP indicates the sulfur isotope discrimination of sulfate reduction is being expressed but not the oxygen isotope effect. An absence of oxygen isotope enrichment but presence of sulfur isotope enrichment can be explained if there is no kinetic isotope effect for oxygen, no back reaction of sulfur intermediates (only the entry of sulfate into the cell is reversible) or if the turnover times of the intracellular intermediate pools where oxygen equilibration can happen are so short that it simply is not expressed. Sulfite is the main sulfur intermediate which enables oxygen isotope exchange and does so in a matter of minutes (Betts and Voss, 1970; Horner and Connick, 2003; Müller et al., 2013; Wankel et al., 2014). Recent theoretical work on intracellular APS and sulfite concentrations has predicted sub-micromolar and millimolar levels respectively (Wing and Halevy, 2014) while measurements in pure cultures grown in batch suggest concentrations of around a hundred micromolar and ten micromolar respectively (Sim et al., 2017). In the first instance, (Wing and Halevy, 2014) assumed the reduction of APS and sulfite is coupled to the oxidation of menaquinone (a mildly reducing electron donor), forcing a high ratio of reduced to oxidized menaquinone to generate a favorable redox potential. This produces a low APS to sulfite ratio of 1:1000 and relatively high sulfite concentrations. Ultimately this results in the intracellular sulfite pool having a large turnover time and enable high oxygen isotope exchange. Contrarily, the measurements of (Sim et al., 2017) in (fast growing) batch cultures suggest the ratio of APS to sulfite is $\sim 10$ :1 with both having relatively low concentrations resulting in a fast turnover time and therefore, less oxygen isotope exchange. A calculation of the turnover times of sulfur within a cell under conditions which produce SALP close to 0 [cell-specific sulfate reduction rate $\approx 50 \mathrm{fmol} / \mathrm{cell} /$ day and assumptions on cellular and intracellular parameters; cell size $=1.5 \times 10^{-18} \mathrm{~m}^{3}$, internal adenosine $5^{\prime}$ phosphosulfate concentration $=0.1-0.001 \mathrm{mM}$, internal sulfite concentration $=10 \mu \mathrm{M}-10 \mathrm{mM}$ (Wing and Halevy, 2014; Sim et al., 2017)] suggests the APS pool is turned over within a fraction of a second $(<<1 \mathrm{~s})$ and the sulfite pool in $0.03-30 \mathrm{~s}$. In these conditions only partial oxygen isotope exchange can occur between sulfite and water. Naturally, as the cell specific sulfate reduction rates in the environment are 2-6 orders of magnitude lower than this calculation, e.g., (Holmkvist et al., 2011), turnover of intracellular metabolites increases from seconds to minutes or hours and the oxygen isotope effect becomes significant. These findings are also in 
agreement with the finding that low csSRR which produce large sulfur isotope fractionations (such as the ones observed in the environment) can only be driven by modestly negative electron carriers (i.e., menaquinone) whereas very negative electron carriers (i.e., ferredoxins) restrict the net fractionation to around $<22 \%$ (Wenk et al., 2017). In most cases, SALP is a direct consequence of these intracellular states. In addition, it is possible that the abundance of different sulfoxy isomers might have an effect on the rate of the isotopic exchange with water as well as on the magnitude of isotope fractionation (Müller et al., 2013; Wankel et al., 2014). These should be incorporated into a kinetic-thermodynamic model as it would enable oxygen isotope exchange to be quantified at the cellular level and be an important tool to predict metabolite cycling within sulfate reducing organisms. For environmental studies, it would allow testing whether cellular-level processes associated with OSR are a fair approximation of environmental observations. This should be a priority of future work.

\section{THE REALISM PHASE}

Empirical studies on AOM-SR have shown a high dependence of sulfur and oxygen isotope fractionation on methane concentrations (Deusner et al., 2014). Unlike pure cultures of sulfate reducing microorganism, AOM-SR is fundamentally incapable of having a zero contribution from $\delta^{18} \mathrm{O}$ in water. In AOM-SR, consortia of archaea and proteobacteria reduce sulfate to sulfide but they do so by disproportionating intermediate sulfur species (Milucka et al., 2012). This leads to the regeneration of $1 / 8^{\text {th }}$ of the reduced sulfate, and an 'inescapable' generation of sulfate with a partial contribution from the isotopic signature of water. However, the oxygen isotope enrichment gained by disproportionation only account partially for the inability of AOM-SR to produce SALP below 0.25. This shunt in the sulfur cycle in AOM-SR accounts for only about $12 \%$ of the total sulfur and is not enough to produce the characteristic range of SALP seen methane-dominated environments (Antler et al., 2015). Contrarily to OSR, AOM-SR requires a degree of reversibility which allows the oxygen isotope exchange of intermediates to be expressed in the sulfate pool even at the highest possible metabolic rates (no methane or sulfate limitation). The fact that the range of SALPs observed in AOM-SR is so narrow is something which remains thus far a perplexing issue that will require further empirical work.

The linear progression of $\delta^{18} \mathrm{O}_{\mathrm{SO} 4}$ vs. $\delta^{34} \mathrm{~S}_{\mathrm{SO} 4}$ in nature (slope of about 0.25 ) is mostly interpreted as an indicator for the ratio between the kinetic isotope effects of $\delta^{34} \mathrm{~S}_{\mathrm{SO} 4}$ and $\delta^{18} \mathrm{O}_{\mathrm{SO} 4}$, where the oxygen fractionation factor is roughly $1 / 4$ of that of sulfur (Mizutani and Rafter, 1969). However, there is no solid evidence for an oxygen kinetic isotope effect in pure cultures of sulfate reducing microorganisms. In fact, pure culture experiments with low SALPs similar to some natural environments and smaller (SALP $=0.25$ ) already show dependence on the oxygen isotope composition of water (Antler et al., 2017), suggesting that the kinetic isotope effect for oxygen isotopes is small or even negligible. Porewater SALPs are evidently more complex than simple kinetic isotope fractionation or equilibrium isotope exchange. An alternative way to reconcile the linear sulfur vs. oxygen isotopes profiles in nature with a small kinetic isotope effect for oxygen may be that SALP is generated by diffusion between two end members, such as seawater sulfate and the enriched $\left(\delta^{34} \mathrm{~S}_{\mathrm{SO}}\right)$ and fully equilibrated $\left(\delta^{18} \mathrm{O}_{\mathrm{SO}}\right)$ pool of sulfate near the sulfate methane transition zone.

In environmental samples, determining if a given SALP is produced by AOM-SR or OSR is challenging for multiple reasons. First, the majority of published work on $\delta^{18} \mathrm{O}_{\mathrm{SO}}$ and $\delta^{34} \mathrm{~S}_{\mathrm{SO}} 4$ does not provide independent, robust evidence of the metabolic processes (AOM-SR or OSR) controlling the pore water profiles. Second, a spatial separation of OSR and AOM-SR at different depths can effectively hide the AOM-SR signature. For example, an abundance of pelagic sites such as from IODP expeditions clearly have a sulfate methane transition zone where sulfate and methane are both consumed. However, OSR in the surface sediment drives $\delta^{18} \mathrm{O}_{\mathrm{SO} 4}$ to equilibrium before AOM-SR has a chance to imprint its signature on the oxygen isotopes. Third, the level of reoxidation occurring in sediments plays an important role in SALP as it increases recycling of the $\delta^{18} \mathrm{O}_{\mathrm{H} 2 \mathrm{O}}$ signature to $\delta^{18} \mathrm{O}_{\mathrm{SO}}$, resulting in a steepening of SALP. Estimating the contribution of reoxidation to the overall sulfur cycle is a large uncertainty in the marine sedimentary sulfur cycle (Jørgensen and Nelson, 2004) and an important aspect of the sulfur cycle where SALP can be a critically important tool, e.g., Brunner et al. (2016).

There is a potential to preserve the SALP signature in sulfate containing minerals, such as barite and celestine and in carbonates (as carbonate associated sulfate) and that it may be a useful indicator of past methane seeps (Feng et al., 2016). Among the three, carbonates are by far more spatially and temporally abundant in the geological record. Authigenic carbonates are more likely to form during AOM-SR due to the reaction stoichiometry, which results in sharp increases in $\mathrm{pH}$ (Soetaert et al., 2007). Therefore, although the SALP cannot distinguish between AOM-SR and high activity OSR, high activity OSR is not associated with extensive carbonate precipitation like AOM-SR.

High carbon isotope fractionation during methanogenesis results in the $\delta^{13} \mathrm{C}$ of the methane being as low as $-100 \%$ (Whiticar, 1999). Since AOM-SR consumes this isotopically light carbon while OSR does not, AOM-SR results in the production of $\delta^{13} \mathrm{C}$-depleted dissolved inorganic carbon, a marker which can be utilized in a quantitative way to estimate the contributions of AOM-SR and OSR to the DIC pool in marine sediments (Martens et al., 1999; Sivan et al., 2007; Malinverno and Pohlman, 2011; Komada et al., 2016). For example, $\delta^{13} \mathrm{C}$ and $\Delta^{14} \mathrm{C}$ of the major carbon pools in the Santa Barbara Basin were used to study the discrepancy of methane and sulfate fluxes to the SMT. Based on the carbon isotope signatures in the resulting DIC pools, OSR could account for $35-45 \%$ of the sulfate consumption in the sulfate methane transition zone (Komada et al., 2016). Such quantitative work, while tedious, is an effective way to differentiate AOM and OSR, which could be utilized in conjunction with $\mathrm{S}-\mathrm{O}$ isotopes to further constrain the nature of carbon mineralization in sediments. Since C-S-O 
isotopes are preserved over geological timescales (as carbonates and carbonate-associated suflates), they should also be useful when applied to the geological record. Isotopically light carbon isotope in lipids have long been known to be a reliable tracer of methanotrophy because of the distinctly light isotope signature of methane (Hinrichs et al., 1999) and carbon isotopes of carbonates associated with AOM-SR are usually light, a tell tale marker of the methanotrophy associated with AOM-SR (Drake et al., 2015). From a quantitative perspective, these markers have limitations because unknown contributions of carbon from nonmethane sources can be incorporated. Non-isotopic quantitative approaches to estimating contributions from AOM-SR and OSR also hold significant promise. For instance, careful comparisons of the fluxes of methane and sulfate into the SMT, combined with in-situ AOM-SR radiotracer incubation experiments e.g., (Beulig et al., 2017) may be able to estimate the relative importance of AOM-SR and OSR in the SMT. A tool which previously held high hopes was molecular approaches to identify microbial community abundances and relate them to process rates, e.g., (Carolan et al., 2015). However, these have thus far been unsuccessful at quantitatively differentiating AOM-SR and OSR. This is in large part because there exists phylogenetic and functional overlap between oxidizing and reducing reactions; for instance ANME and methanogens, e.g., (McGlynn, 2017) or sulfide oxidizers and sulfate reducers, e.g., (Thorup et al., 2017) which makes it impossible to ascertain which organism is doing what in the subsurface. Molecular approaches are unlikely to yield quantitatively useful information by themselves until significant progress is made in connecting genotypes to metabolic functions.

SALP provides a powerful tool to study the sulfur cycle, by sensitively responding to changes in the reduction of sulfate vs. the oxidation of reduce sulfur compounds. In this

\section{REFERENCES}

Aharon, P., and Fu, B. (2000). Microbial sulfate reduction rates and sulfur and oxygen isotope fractionations at oil and gas seeps in deepwater Gulf of Mexico. Geochim. Cosmochim. Acta 64, 233-246. doi: 10.1016/S0016-7037(99) 00292-6

Aharon, P., and Fu, B. (2003). Sulfur and oxygen isotopes of coeval sulfate-sulfide in pore fluids of cold seep sediments with sharp redox gradients. Chem. Geol. 195, 201-218. doi: 10.1016/S0009-2541(02)00395-9

Aller, R. C., Madrid, V., Chistoserdov, A., Aller, J. Y., and Heilbrun, C. (2010). Unsteady diagenetic processes and sulfur biogeochemistry in tropical deltaic muds: implications for oceanic isotope cycles and the sedimentary record. Geochim. Cosmochim. Acta 74, 4671-4692. doi: 10.1016/j.gca.2010.05.008

Antler, G. (2012). Multiple Stable Isotopes a Tool for Studying the Mechanism of Bacterial Sulfate Reduction, Geological Sciences. Beersheba: Ben-Gurion University of the Negev.

Antler, G., Turchyn, A. V., Herut, B., Davies, A., Rennie, V. C. F., and Sivan, O. (2014). Sulfur and oxygen isotope tracing of sulfate driven anaerobic methane oxidation in estuarine sediments. Estuar. Coast. Shelf Sci. 142, 4-11. doi: 10. 1016/j.ecss.2014.03.001

Antler, G., Turchyn, A. V., Herut, B., and Sivan, O. (2015). A unique isotopic fingerprint of sulfate-driven anaerobic oxidation of methane. Geology 43, 619-622. doi: 10.1130/G36688.1

Antler, G., Turchyn, A. V., Ono, S., Sivan, O., and Bosak, T. (2017). Combined $34 \mathrm{~S}, 33 \mathrm{~S}$ and $18 \mathrm{O}$ isotope fractionations record different intracellular steps of microbial sulfate reduction. Geochim. Cosmochim. Acta 203, 364-380. doi: 10.1016/j.gca.2017.01.015 contribution, we explored the limitation of this tool as a way to distinguish between AOM-SR and OSR. Because of the multiple parameters which control the extent of SALP, the information provided and what it tells of the microbial sulfur transformations are not generally applicable to all circumstances. However, with a careful site-specific approach and in combination with other proxies, SALP can contribute vital information on the microbial and chemical reactions taking place in marine sediments. Further refining (1) our understanding on the magnitude of the oxygen isotope kinetic fractionation during the APS reduction to sulfite, (2) the degree of oxygen isotope exchange between sulfur intermediates and water and (3) its relationship to the cell specific sulfate reduction rate, would greatly improve our ability to interpret the SALP as an indicator of the microbial transformations taking place. Doing so will transform this analytical tool into a reliable proxy of sulfur cycling.

\section{AUTHOR CONTRIBUTIONS}

Both authors contributed to the redaction of the manuscript and figures.

\section{ACKNOWLEDGMENTS}

We would like to thank Harold J. Bradbury, Sambuddha Misra, Jacquelynn Ward, Felix Beulig, and Alexander Michaud for their comments. AP acknowledges the Danish National Research Foundation [DNRF104] and the European Research Council [294200].

Antler, G., Turchyn, A. V., Rennie, V., Herut, B., and Sivan, O. (2013). Coupled sulfur and oxygen isotope insight into bacterial sulfate reduction in the natural environment. Geochim. Cosmochim. Acta 118, 98-117. doi: 10.1016/j.gca.2013. 05.005

Avrahamov, N., Antler, G., Yechieli, Y., Gavrieli, I., Joye, S., Saxton, M., et al. (2014). Anaerobic oxidation of methane by sulfate in hypersaline groundwater of the Dead Sea aquifer. Geobiology 12, 511-528. doi: 10.1111/gbi.12095

Betts, R. H., and Voss, R. H. (1970). The kinetics of oxygen exchange between the sulfite ion and water. Can. J. Chem. 48, 2035-2041. doi: 10.1139/v70-339

Beulig, F., Røy, H., Glombitza, C., and Jørgensen, B. B. (2017). Control on rate and pathway of anaerobic organic carbon degradation in the seabed. Proc. Natl. Acad. Sci. U.S.A. 115:201715789. doi: 10.1073/pnas.1715789115

Blake, R. E., Surkov, A. V., Böttcher, M. E., Ferdelman, T. G., and Jørgensen, B. B. (2006). "Oxygen isotope composition of dissolved sulfate in deep-sea sediments: eastern equatorial Pacific Ocean," in Proceedings of the Ocean Drilling Program, Scientific Results, eds B. B. Jørgensen, S. L. D’Hondt and D. J. Miller (College Station, TX: Ocean Drilling Program), 1-24. doi: 10.2973/odp.proc.sr.201.116. 2006

Blonder, B., Boyko, V., Turchyn, A. V., Antler, G., Sinichkin, U., Knossow, N., et al. (2017). Impact of Aeolian dry deposition of reactive iron minerals on sulfur cycling in sediments of the Gulf of Aqaba. Front. Microbiol. 8:1131. doi: $10.3389 /$ fmicb.2017.01131

Boetius, A., Ravenschlag, K., Schubert, C. J., Rickert, D., Widdel, F., Gieseke, A., et al. (2000). A marine microbial consortium apparently mediating anaerobic oxidation of methane. Nature 407, 623-626. doi: 10.1038/35036572

Böttcher, M. E., Bernasconi, S. M., and Brumsack, H. J. (1999). Carbon, sulfur, and oxygen isotope geochemistry of interstitial waters from the Western 
Mediterranean. Proc. Ocean Drill. Prog. 161, 413-421. doi: 10.2973/odp.proc. sr.161.229.1999

Böttcher, M. E., Brumsack, H. J., and de Lange, G. J. (1998). "Sulfate reduction and related stable isotope $(34 \mathrm{~S}, 18 \mathrm{O})$ variations in interstitial waters from the eastern Mediterranean," in Proceedings of the Ocean Drilling Program, Scientific Results (College Station, TX: Ocean Drilling Program), 365-373. doi: 10.2973/ odp.proc.sr.160.002.1998

Böttcher, M. E., Ferdelman, T. G., Jørgensen, B. B., Blake, R. E., Surkov, A. V., and Claypool, G. E. (2006). "Sulfur isotope fractionation by the deep biosphere within sediments of the eastern equatorial Pacific and Peru margin," in Proceedings of the Ocean Drilling Program, Scientific Results, eds B. B. Jørgensen, S. L. D'Hondt and D. J. Miller (College Station, TX: Ocean Drilling Program), 1-21. doi: 10.2973/odp.proc.sr.201.109.2006

Böttcher, M. E., and Thamdrup, B. (2001). Anaerobic sulfide oxidation and stable isotope fractionation associated with bacterial sulfur disproportionation in the presence of MnO2. Geochim. Cosmochim. Acta 65, 1573-1581. doi: 10.1016/ S0016-7037(00)00622-0

Böttcher, M. E., Thamdrup, B., Gehre, M., and Theune, A. (2005). 34S/32S and $18 \mathrm{O} / 16 \mathrm{O}$ fractionation during sulfur disproportionation by Desulfobulbus propionicus. Geomicrobiol. J. 22, 219-226. doi: 10.1080/0149045059094 7751

Böttcher, M. E., Thamdrup, B., and Vennemann, T. W. (2001). Oxygen and sulfur isotope fractionation during anaerobic bacterial disproportionation of elemental sulfur. Geochim. Cosmochim. Acta 65, 1601-1609. doi: 10.1016/ S0016-7037(00)00628-1

Brunner, B., Arnold, G. L., Røy, H., Müller, I. A., and Jørgensen, B. B. (2016). Off limits: sulfate below the sulfate-methane transition. Front. Earth Sci. 4:75. doi: $10.3389 /$ feart.2016.00075

Brunner, B., and Bernasconi, S. M. (2005). A revised isotope fractionation model for dissimilatory sulfate reduction in sulfate reducing bacteria. Geochim. Cosmochim. Acta 69, 4759-4771. doi: 10.1016/j.gca.2005.04.015

Brunner, B., Bernasconi, S. M., Kleikemper, J., and Schroth, M. H. (2005). A model for oxygen and sulfur isotope fractionation in sulfate during bacterial sulfate reduction processes. Geochim. Cosmochim. Acta 69, 4773-4785. doi: 10.1016/j. gca.2005.04.017

Carolan, M. T., Smith, J. M., and Beman, J. M. (2015). Transcriptomic evidence for microbial sulfur cycling in the eastern tropical North Pacific oxygen minimum zone. Front. Microbiol. 6:334. doi: 10.3389/fmicb.2015.00334

Crémière, A., Strauss, H., Sebilo, M., Hong, W.-L., Gros, O., Schmidt, S., et al. (2017). Sulfur diagenesis under rapid accumulation of organic-rich sediments in a marine mangrove from Guadeloupe (French West Indies). Chem. Geol. 454, 67-79. doi: 10.1016/j.chemgeo.2017.02.017

Deusner, C., Holler, T., Arnold, G. L., Bernasconi, S. M., Formolo, M. J., and Brunner, B. (2014). Sulfur and oxygen isotope fractionation during sulfate reduction coupled to anaerobic oxidation of methane is dependent on methane concentration. Earth Planet. Sci. Lett. 399, 61-73. doi: 10.1016/j.epsl.2014. 04.047

Dickens, G. R., O'Neil, J. R., Rea, D. K., and Owen, R. M. (1995). Dissociation of oceanic methane hydrate as a cause of the carbon isotope excursion at the end of the Paleocene. Paleoceanography 10, 965-971. doi: 10.1029/95PA 02087

Drake, H., Åström, M. E., Heim, C., Broman, C., Åström, J., Whitehouse, M., et al. (2015). Extreme 13C depletion of carbonates formed during oxidation of biogenic methane in fractured granite. Nat. Commun. 6:7020. doi: 10.1038/ ncomms 8020

Einsiedl, F., Pilloni, G., Ruth-Anneser, B., Lueders, T., and Griebler, C. (2015). Spatial distributions of sulphur species and sulphate-reducing bacteria provide insights into sulphur redox cycling and biodegradation hot-spots in a hydrocarbon-contaminated aquifer. Geochim. Cosmochim. Acta 156, 207-221. doi: 10.1016/j.gca.2015.01.014

Elderfield, H. (2002). Foraminiferal Mg/Ca Paleothermometry: Expected Advances and Unexpected Consequences Goldschmidt Conference. Davos: Cambridge Publications.

Feng, D., Peng, Y., Bao, H., Peckmann, J., Roberts, H. H., and Chen, D. (2016). A carbonate-based proxy for sulfate-driven anaerobic oxidation of methane. Geology 44, 999-1002. doi: 10.1130/G38233.1

Fritz, P., Basharmal, G., Drimmie, R., Ibsen, J., and Qureshi, R. (1989). Oxygen isotope exchange between sulphate and water during bacterial reduction of sulphate. Chem. Geol. Isot. Geosci. Sect. 79, 99-105. doi: 10.1016/0168-9622(89) 90012-2

Gilhooly, W. P. III, Reinhard, C. T., and Lyons, T. W. (2016). A comprehensive sulfur and oxygen isotope study of sulfur cycling in a shallow, hyper-euxinic meromictic lake. Geochim. Cosmochim. Acta 189, 1-23. doi: 10.1016/j.gca.2016. 05.044

Glombitza, C., Jaussi, M., Røy, H., Seidenkrantz, M.-S., Lomstein, B. A., and Jørgensen, B. B. (2015). Formate, acetate, and propionate as substrates for sulfate reduction in sub-arctic sediments of Southwest Greenland. Front. Microbiol. 6:846. doi: 10.3389/fmicb.2015.00846

Gomes, M. L., and Johnston, D. T. (2017). Oxygen and sulfur isotopes in sulfate in modern euxinic systems with implications for evaluating the extent of euxinia in ancient oceans. Geochim. Cosmochim. Acta 205, 331-359. doi: 10.1016/j.gca. 2017.02.020

Hinrichs, K.-U., Hayes, J. M., Sylva, S. P., Brewer, P. G., and DeLong, E. F. (1999). Methane-consuming archaebacteria in marine sediments. Nature 398, 802-805. doi: $10.1038 / 19751$

Holmkvist, L., Ferdelman, T. G., and Jørgensen, B. B. (2011). A cryptic sulfur cycle driven by iron in the methane zone of marine sediment (Aarhus Bay, Denmark. Geochim. Cosmochim. Acta 75, 3581-3599. doi: 10.1016/j.gca.2011.03.033

Horner, D. A., and Connick, R. E. (2003). Kinetics of oxygen exchange between the two isomers of bisulfite ion, disulfite ion (S2O52-), and water as studied by oxygen-17 nuclear magnetic resonance spectroscopy. Inorg. Chem. 42, 1884-1894. doi: 10.1021/ic020692n

Jørgensen, B. B., and Nelson, D. C. (2004). Sulfide oxidation in marine sediments: geochemistry meets microbiology. Geol. Soc. Am. Spec. Pap. 379, 63-81. doi: 10.1130/0-8137-2379-5.63

Knossow, N., Blonder, B., Eckert, W., Turchyn, A. V., Antler, G., and Kamyshny, A. (2015). Annual sulfur cycle in a warm monomictic lake with sub-millimolar sulfate concentrations. Geochem. Trans. 16:7. doi: 10.1186/s12932-015-0021-5

Komada, T., Burdige, D. J., Li, H.-L., Magen, C., Chanton, J. P., and Cada, A. K. (2016). Organic matter cycling across the sulfate-methane transition zone of the Santa Barbara Basin. California Borderland. Geochim. Cosmochim. Acta 176, 259-278. doi: 10.1016/j.gca.2015.12.022

Kvenvolden, K. A. (1988). Methane hydrate - a major reservoir of carbon in the shallow geosphere? Chem. Geol. 71, 41-51. doi: 10.1016/0009-2541(88) 90104-0

Malinverno, A., and Pohlman, J. W. (2011). Modeling sulfate reduction in methane hydrate-bearing continental margin sediments: does a sulfatemethane transition require anaerobic oxidation of methane. Geochem. Geophys. Geosyst. 12:Q07006. doi: 10.1029/2011GC003501

Mandernack, K. W., and Skei, J. M. (2003). A stable sulfur and oxygen isotopic investigation of sulfur cycling in an anoxic marine basin, Framvaren Fjord, Norway. Chem. Geol. 195, 181-200. doi: 10.1016/S0009-2541(02)00394-7

Martens, C. S., Albert, D., and Alperin, M. J. (1999). Stable isotope tracing of anaerobic methane oxidation in the gassy sediments of Eckernförde Bay, German Baltic Sea. Am. J. Sci. 299, 589-610. doi: 10.2475/ajs.299.7-9.589

McGlynn, S. E. (2017). Energy metabolism during anaerobic methane oxidation in ANME archaea. Microbes Environ. 32, 5-13. doi: 10.1264/jsme2.ME16166

Mills, J. V., Antler, G., and Turchyn, A. V. (2016). Geochemical evidence for cryptic sulfur cycling in salt marsh sediments. Earth Planet. Sci. Lett. 453, 23-32. doi: 10.1016/j.epsl.2016.08.001

Milucka, J., Ferdelman, T. G., Polerecky, L., Franzke, D., Wegener, G., Schmid, M., et al. (2012). Zero-valent sulphur is a key intermediate in marine methane oxidation. Nature 491, 541-546. doi: 10.1038/nature11656

Mizutani, Y., and Rafter, T. A. (1969). Oxygen isotopic composition of sulphate. Part 4. Bacterial fractionation of oxygen isotopes in the reduction of sulphate and in the oxidation of sulphur. N. Z. J. Sci. 12, 60-68.

Müller, I. A., Brunner, B., and Coleman, M. (2013). Isotopic evidence of the pivotal role of sulfite oxidation in shaping the oxygen isotope signature of sulfate. Chem. Geol. 354, 186-202. doi: 10.1016/j.chemgeo.2013.05.009

Riedinger, N., Brunner, B., Formolo, M. J., Solomon, E., Kasten, S., Strasser, M., et al. (2010). Oxidative sulfur cycling in the deep biosphere of the Nankai Trough, Japan. Geology 38, 851-854. doi: 10.1130/G31085.1

Rubin-Blum, M., Antler, G., Turchyn, A. V., Tsadok, R., Goodman-Tchernov, B. N., Shemesh, E., et al. (2014). Hydrocarbon-related microbial processes in the deep sediments of the Eastern Mediterranean Levantine Basin. FEMS Microbiol. Ecol. 87, 780-796. doi: 10.1111/1574-6941.12264 
Sim, M. S., Paris, G., Adkins, J. F., Orphan, V. J., and Sessions, A. L. (2017). Quantification and isotopic analysis of intracellular sulfur metabolites in the dissimilatory sulfate reduction pathway. Geochim. Cosmochim. Acta 206, 57-72. doi: 10.1016/j.gca.2017.02.024

Sivan, O., Antler, G., Turchyn, A. V., Marlow, J. J., and Orphan, V. J. (2014). Iron oxides stimulate sulfate-driven anaerobic methane oxidation in seeps. Proc. Natl. Acad. Sci. U.S.A. 111, 4139-4147. doi: 10.1073/pnas.14122 69111

Sivan, O., Schrag, D. P., and Murray, R. W. (2007). Rates of methanogenesis and methanotrophy in deep-sea sediments. Geobiology 5, 141-151. doi: 10.1111/j. 1472-4669.2007.00098.x

Soetaert, K., Hofmann, A. F., Middelburg, J. J., Meysman, F. J. R., and Greenwood, J. (2007). The effect of biogeochemical processes on $\mathrm{pH}$. Mar. Chem. 105, 30-51. doi: 10.1016/j.marchem.2006.12.012

Strauss, H., Bast, R., Cording, A., Diekrup, D., Fugmann, A., GarbeSchonberg, D., et al. (2012). Sulphur diagenesis in the sediments of the Kiel Bight, SW Baltic Sea, as reflected by multiple stable sulphur isotopes. Isotopes Environ. Health Stud. 48, 166-179. doi: 10.1080/10256016.2012. 648930

Thorup, C., Schramm, A., Findlay, A. J., Finster, K. W., and Schreiber, L. (2017). Disguised as a Sulfate Reducer: growth of the Deltaproteobacterium Desulfurivibrio alkaliphilus by sulfide oxidation with Nitrate. mBio 8:e00671-17. doi: $10.1128 / \mathrm{mBio} .00671-17$

Turchyn, A., Sivan, O., and Schrag, D. (2006). Oxygen isotopic composition of sulfate in deep sea pore fluid: evidence for rapid sulfur cycling. Geobiology 4, 191-201. doi: 10.1111/j.1472-4669.2006. 00079.x

Turchyn, A. V., Antler, G., Byrne, D., Miller, M., and Hodell, D. A. (2016). Microbial sulfur metabolism evidenced from pore fluid isotope geochemistry at Site U1385. Glob. Planet. Change 141, 82-90. doi: 10.1016/j.gloplacha.2016. 03.004

Wankel, S. D., Bradley, A. S., Eldridge, D. L., and Johnston, D. T. (2014). Determination and application of the equilibrium oxygen isotope effect between water and sulfite. Geochim. Cosmochim. Acta 125, 694-711. doi: 10.1016/j.gca.2013.08.039

Wenk, C. B., Wing, B. A., and Halevy, I. (2017). Electron carriers in microbial sulfate reduction inferred from experimental and environmental sulfur isotope fractionation. ISME J. doi: 10.1038/ismej.2017.185 [Epub ahead of print].

Whiticar, M. J. (1999). Carbon and hydrogen isotope systematics of bacterial formation and oxidation of methane. Chem. Geol. 161, 291-314. doi: 10.1016/ S0009-2541(99)00092-3

Whiticar, M. J., Faber, E., and Schoell, M. (1986). Biogenic methane formation in marine and freshwater environments: $\mathrm{CO} 2$ reduction vs. acetate fermentationIsotope evidence. Geochim. Cosmochim. Acta 50, 693-709. doi: 10.1016/00167037(86)90346-7

Wing, B. A., and Halevy, I. (2014). Intracellular metabolite levels shape sulfur isotope fractionation during microbial sulfate respiration. Proc. Natl. Acad. Sci. U.S.A. 111, 18116-18125. doi: 10.1073/pnas.1407502111

Wortmann, U. G., Chernyavsky, B., Bernasconi, S. M., Brunner, B., Böttcher, M. E., and Swart, P. K. (2007). Oxygen isotope biogeochemistry of pore water sulfate in the deep biosphere: dominance of isotope exchange reactions with ambient water during microbial sulfate reduction (ODP Site 1130). Geochim. Cosmochim. Acta 71, 4221-4232. doi: 10.1016/j.gca.2007.06.033

Wuebbles, D. J., and Hayhoe, K. (2002). Atmospheric methane and global change. Earth Sci. Rev. 57, 177-210. doi: 10.1016/S0012-8252(01)00062-9

Conflict of Interest Statement: The authors declare that the research was conducted in the absence of any commercial or financial relationships that could be construed as a potential conflict of interest.

Copyright (c) 2018 Antler and Pellerin. This is an open-access article distributed under the terms of the Creative Commons Attribution License (CC BY). The use, distribution or reproduction in other forums is permitted, provided the original author(s) and the copyright owner are credited and that the original publication in this journal is cited, in accordance with accepted academic practice. No use, distribution or reproduction is permitted which does not comply with these terms. 